\title{
Ramón Gaya en Mi POEsía ${ }^{1}$
}

Eloy SÁnchez Rosillo

\author{
LA ESPERA \\ (Homenaje a Ramón Gaya)
}

Ésta es mi soledad, verme rodeado de luz.

NIETZSCHE

SE acerca a la ventana, y a través del cristal sus ojos siguen el curso de esas nubes tan blancas que cruzan indolentes el cielo azul de la mañana. Y muy conforme observa cómo se duerme el sol en la quietud de los tejados, mientras todo está bien y apenas hay transcurso.

La luz llena el estudio, y los pocos enseres que ha ido el vivir reuniendo en esta habitación están aquí en su sitio, y se diría que acompañan gustosamente con su silencio inanimado al hombre que ahora abandona la ventana y se acerca despacio a ese cuadro aún vacío, a los pinceles que aguardan el instante de dejarse llevar con mansedumbre por una mano limpia y conocida.

Se ve sobre una mesa una copa con agua, y en ella unos jazmines. Él los mira, y quisiera entender el secreto de estas pequeñas flores, el enigma de su perfume leve, de su frágil blancura, para poder más tarde dejar temblando sobre el lienzo la cerrada belleza que lo conmueve y permanece ajena a su emoción, a sus afanes, inconquistada y sola, desvalida.

\footnotetext{
${ }^{1}$ Los tres poemas están recogidos hoy en Las cosas como fueron. Poesía completa, 1974-2017,
} Barcelona, Tusquets Editores, 2018, págs. 124-126, 396-399 y 670-671, respectivamente. 
Pero siente que el momento de hacer suya esta hermosura, de confundirse con su ser, no ha comenzado aún, y se retira con humildad, se aparta de ese lugar radiante. Y vaga por el cuarto, decidido a esperar a que madure el tiempo en que la realidad palpitante que ansía, dulcemente, sin lucha, se le entregue.

Se sienta en una silla. Abre un libro. Regresa a los versos sabidos de algún poeta amado. Después, durante un rato, lo acompaña la música, y perdido en la mágica intimidad de una sonata piensa quizás, involuntariamente, en ciertas cosas del pasado, cosas que fueron suyas y fue perdiendo luego: la ciudad delicada y polvorienta, dormida bajo el sol, en la que vio la luz; los no olvidados huertos de su niñez; aquellos quietos días en que todo era simple, sin daño, consistente, y estaba anclado en un rincón del paraíso.

Cesó luego el encanto. La vida se echó a andar y dentro de ella germinó la muerte. El muchacho lo supo, y advirtió que en lo profundo de su pecho había una extraña inquietud, un anhelo infinito de fijar de algún modo -en un papel, acaso sobre un lienzolos efímeros dones del mundo. $Y$ desde entonces se entregó con pasión a su quimera, quiso arder para siempre en la llama intensísima de ese empeño exclusivo.

La soledad le ha dado compañía, y lo ha ayudado a defender su fe, a no dejar jamás que se apagara la sagrada ilusión. Ella lo ha conducido -fiel a sí mismo, libre, intacto y puro-, a través de los años, hasta esa silla en la que hoy recuerda o tal vez sueña mientras suena la música. 
Todo se acalla al cabo. Y el profundo silencio despierta al soñador. Contempla de nuevo los jazmines, la transparencia de la copa y los alegres juegos de la luz en el cristal que brilla.

Y de repente oye como un rumor de misteriosas aguas, y se siente invadido por la presencia súbita de un poder que lo impulsa a coger el pincel y aproximarse al lienzo.

Y casi sin esfuerzo, casi a pesar de él mismo, su mano va sacando poco a poco de la oquedad del cuadro la verdad trascendida del cristal y las flores, que aquí, sobre la tela, salvados ya del tiempo y del olvido, ofrecen su inocencia temblorosa y son al fin imagen viva del amor, cifra del universo.

(De Páginas de un diario, 1981)

\section{PORQUE NADA TERMINA \\ (Ramón Gaya)}

ES preciso que todo en apariencia acabe para que al fin comience. Sólo entonces los hechos de nuestro acontecer desordenado adquieren poco a poco la rara consistencia indestructible del sueño o la leyenda; sólo entonces podemos comprender lo vivido, completarlo, abrazar sin temores ni asechanzas, interminablemente, la maravilla cierta del vivir. 
Cuando pienso, Ramón -después del trance natural de tu muerte-, en los años aquellos en los que coincidimos en el mundo, siento que me estremece el misterio absoluto que es la vida. Qué suerte para mí tan inmensa y extraña, inexplicable y misericordiosa, fue el que nos condujeran nuestros pasos -a través de avatares cuyo oculto sentido cifrado permaneceal día y a la hora y al lugar en que nos conocimos; y qué providencial para el que soy que en sí mismo llevara nuestro encuentro la bendita semilla de una amistad tan larga y luminosa. ¿Es esto mero arbitrio de la casualidad? Es destino y enigma. A cierta edad un hombre no se engaña y sabe lo que ha sido en su existencia de veras decisivo. No ignoro que sin duda tú en la mía lo fuiste, y es imposible y triste imaginarla sin tu ejemplo constante, y sin la relación tan duradera que mantuve contigo y con tu obra.

Sí, yo he estado muy cerca muchas veces de increíbles prodigios.

Vi surgir tu pintura del abismo del lienzo y pude contemplar cómo sus formas vivas lentamente empezaban a respirar despacio al llegar a este mundo.

Con frecuencia, asimismo, sabía del fulgor de tus escritos nuevos antes de publicarse, y tuve el privilegio de escuchártelos. 
Tu obra es patrimonio de cuantos quieran que les pertenezca. Pero, además de compartir tan fértil y tan bella heredad con los que la hacen suya, yo fui también testigo de tu vida, y eso sólo unos pocos lo hemos sido. Ineludible obligación gustosa y legítimo orgullo mueven y moverán mi ánimo y mi lengua al testimonio fiel.

No encuentro en la memoria lances que te afectaran y en los que tu persona (aun teniendo sin duda sus flaquezas también) no rayase a la altura de la imagen señera que en quienes te tratamos proyectabas. Hondura y gravedad no te impedían ser diáfano y alegre. Nunca he visto a nadie menos dado a complacerse en sus propias miserias y desdichas, aunque al igual que a todos, e incluso más que a muchos, la angustia y la tragedia te salieran al paso y en tu ser pretendieran en vano agazaparse. Severo y exigente contigo y con los otros hasta extremosos límites, y generoso y comprensivo al cabo, sin componendas ni renunciaciones. Ahora estoy acordándome de tus ojos vivísimos, que hasta el fondo miraban con rigor y ternura. Y recuerdo tu voz tan íntima y serena, tu voz que por costumbre, sin excepciones, iba a buscar las palabras hasta el origen mismo sagrado de las cosas.

Nada de cuanto digo se extingue con tu muerte. 
Tras esa puerta estrecha, oscura y necesaria que un día atravesaste, continúa el camino, ya sin riesgo ninguno de que discurra por lugar baldío ni de que, como pudo suceder, nos resultara ajeno su trazado. Que los muertos entierren a sus muertos y la ceniza vaya a la ceniza.

Tu luz y tu verdad entre nosotros siguen $\mathrm{y}$ han de seguir, tan vivas y tan puras como en cualquier momento, limpias de escorias y de contingencias.

Es preciso que todo transcurra y se remanse, que al parecer concluya para que al fin empiece. Porque todo está siempre comenzando. Porque nada termina.

\section{BAJO EL SOL DE LA TARDE (Con Ramón Gaya)}

HACE viento esta tarde, un viento frío, del norte, pero que gira y se enmaraña a ratos. Es lo propio de un día como éste, ya el último de enero. Y hace a la vez mucho sol, lumbre alegre, insumisa a los dictados del invierno huraño. Sentado en este rincón de mi terraza que me pone al abrigo por completo del airazo cambiante, soy dichoso leyendo a Ramón Gaya, mientras del cielo llega hasta mi vida un bien que me redime. Son apenas las cinco. Me queda todavía una hora al menos antes de que comience a caer la humedad y a oscurecer, una hora inmensa 
para seguir con las anotaciones del Diario de un pintor, inagotable libro, recién escrito siempre cuando mis manos lo abren y se adentran despacio en su decir mis ojos;

lleno también de sol en cada línea -el sol de la belleza y la verdad, de la obediencia-, oro joven de aurora o intenso de crepúsculo, fulgor de mediodía, por lo certero y por lo cenital. Su viva luz sin tacha entra en mí y me ilumina.

Se oye el mar enojado consigo mismo; se oye el viento, que se enreda en las copas de los árboles y suena muy semejante al mar. En el pecho cobijo una por una las palabras de aquel que tantos años fue mi amigo y al que hoy tan cerca siento, tan aquí. La tarde ocurre lenta. Y todo va cumpliéndose. 